\title{
The Zymoseptoria tritici ORFeome: A Functional Genomics Community Resource
}

\author{
Yogesh Chaudhari, ${ }^{1}$ Timothy C. Cairns, ${ }^{1}$ Yaadwinder Sidhu, ${ }^{1}$ Victoria Attah, ${ }^{1}$ Graham Thomas, ${ }^{1}$ \\ Michael Csukai, ${ }^{2}$ Nicholas J. Talbot, ${ }^{3, \dagger}$ David J. Studholme, ${ }^{1, \dagger}$ and Ken Haynes ${ }^{1}$ \\ ${ }^{1}$ Biosciences, University of Exeter, Exeter EX4 4QD, U.K. \\ ${ }^{2}$ Syngenta, Jealott's Hill International Research Centre, Bracknell, RG42 6EY, U.K. \\ ${ }^{3}$ The Sainsbury Laboratory, University of East Anglia, Norwich Research Park, NR47UH, U.K.
}

\begin{abstract}
Libraries of protein-encoding sequences can be generated by identification of open reading frames (ORFs) from a genome of choice that are then assembled into collections of plasmids termed ORFeome libraries. These represent powerful resources to facilitate functional genomic characterization of genes and their encoded products. Here, we report the generation of an ORFeome for Zymoseptoria tritici, which causes the most serious disease of wheat in temperate regions of the world. We screened the genome of strain IP0323 for high confidence gene models, identifying 4,075 candidates from 10,933 predicted genes. These were amplified from genomic DNA, were cloned into the Gateway entry vector pDONR207, and were sequenced, providing a total of 3,022 quality-controlled plasmids. The ORFeome includes genes predicted to encode effectors $(n=410)$ and secondary metabolite biosynthetic proteins $(n=171)$ in addition to genes residing at dispensable chromosomes $(n=122)$ or those that are preferentially expressed during plant infection $(n=527)$. The ORFeome plasmid library is compatible with our previously developed suite of Gateway destination vectors, which have various combinations of promoters, selection markers, and epitope tags. The $Z$. tritici ORFeome constitutes a powerful resource for functional genomics and offers unparalleled opportunities to understand the biology of $Z$. tritici.
\end{abstract}

Fungal pathogens kill more people per year than malaria and result in crop destruction or postharvest spoilage that destroys enough food to feed approximately $10 \%$ of the human population (Denning and Bromley 2015; Fisher et al. 2012). Technological advances in fungal genomics, transcriptomics, proteomics, metabolomics, bioinformatics, and network analyses,

Yogesh Chaudhari and Timothy C. Cairns contributed equally to this study.

This paper is dedicated to the memory of Ken Haynes, who led the study and was an outstanding fungal biologist as well as an inspirational colleague, friend, and mentor to his fellow co-authors.

Raw sequencing data is available at the Sequencing Read Archive (accession numbers SRX1267196 and SRX1265386).

${ }^{\dagger}$ Corresponding authors: D. J. Studholme; D.J.Studholme@exeter.ac.uk and, for plasmid requests, N. Talbot: nick.talbot@tsl.ac.uk or weibin.ma@tsl.ac.uk

Current address for Timothy C. Cairns: Tianjin Institute of Industrial Biotechnology, Chinese Academy of Sciences, Tianjin, 300308, China

*The $e$-Xtra logo stands for "electronic extra" and indicates that one supplementary figure and two supplementary files are published online.

The author(s) declare no conflict of interest.

Accepted for publication 1 July 2019.

\section{Funding}

The work was supported by the Biotechnology and Biological Sciences Research Council (BBSRC) BBR grant to $\mathrm{K}$. Haynes and collaborators (BB/ 1025956/1) and a BBSRC CASE studentship (BB/J500793/1) supported by Syngenta UK to Y. Sidhu.

\section{Keywords}

ORFeome, Zymoseptoria tritici, Mycosphaerella graminicola, functional genomics 
however, now enable pathogenic fungi to be studied as integrated systems, providing unparalleled opportunities to understand their biology (Cairns et al. 2016; Meyer et al. 2016). Functional genomic approaches, which define the function and interactions of genes and their encoded products at a genome or near-genome level, are increasingly used to dissect host-pathogen interactions, virulence factors, drug resistance, and infectious growth during fungal disease (Chauvel et al. 2012; Jeon et al. 2007; Legrand et al. 2018; Schwarzmüller et al. 2014; Son et al. 2011). However, a significant constraint to conducting functional genomic experiments are high reagent and labor costs, due to the necessity to study thousands or tens of thousands of genes from a given fungal pathogen.

In order to obviate this challenge, community-accessible libraries have been developed, which consist of hundreds or thousands of either individual genes, null mutant, or overexpression strains, which ultimately enable facile and high-throughput experimentation by the end user at a minimal expense (Dunlap et al. 2007; Giaever and Nislow 2014; Giaever et al. 2002; Homann et al. 2009; Liu et al. 2008; Noble et al. 2010; Roemer et al. 2003; Winzeler et al. 1999). ORFeomes are collections of open reading frames (ORFs) that are encoded in a library of plasmid vectors. These resources have been generated for several model organisms, including humans, Escherichia coli, Caenorhabditis elegans, and Arabidopsis thaliana (Gong et al. 2004; Lamesch et al. 2004; Li et al. 2008; Matsuyama et al. 2006; Rajagopala et al. 2010; Wiemann et al. 2016). ORFeomes have also been developed for the fungal kingdom, including fission yeast (Matsuyama et al. 2006), budding yeast (Gelperin et al. 2005) and, most recently, the human pathogenic yeast Candida albicans (Legrand et al. 2018). Usually, ORFeomes are compatible with the Gateway cloning technology (Invitrogen), which enables rapid and high-throughput recombinase-based transfer of an ORF coding sequence to generate expression vectors (Alberti et al. 2007; Walhout et al. 2000). Community access to hundreds or thousands of such plasmids in a single library enables highly flexible generation of expression vectors for high-throughput functional genomic experiments.

The filamentous ascomycete fungus Zymoseptoria tritici (previously Mycosphaerella graminicola) (Talbot 2015) causes Septoria tritici blotch, an important foliar disease of wheat (Fones and Gurr 2015). Z. tritici is a significant threat to international food security, and, even with access to some resistant wheat cultivars and frequent fungicide applications, the estimated average yield losses due to this pathogen are still 10\% (Fones and Gurr 2015). Even more strikingly, approximately $70 \%$ of agricultural fungicides in Europe are deployed to control just this single disease (Goodwin et al. 2011), which likely drives triazole resistance in fungal pathogens of humans as well as plants (Chowdhary et al. 2013). These challenges are compounded by very high levels of genome plasticity and gene flow between populations of Z. tritici (Möller et al. 2018; Zhan et al. 2003).

The first genome sequence of $Z$. tritici (isolate IP0323) revealed 10,933 predicted genes located on 13 core and eight dispensable chromosomes (Goodwin et al. 2011). Deletion of the dispensable chromosomes confirmed that some are necessary for host specificity (Habig et al. 2017) and enable remarkably high rates of genome plasticity and spontaneous chromosome loss (Möller et al. 2018). Recent construction and analysis of a Z. tritici pangenome suggests a core set of 9,149 genes (Plissonneau et al. 2018). With regards to understanding the mechanistic basis of host infection, studies have characterized the underlying $Z$. tritici cellular biology and infectious growth (King et al. 2017; Steinberg 2015), transcriptionally deployed secondary metabolite loci (Cairns and Meyer 2017; Rudd et al. 2015), and components of the secreted effector arsenal (Kettles et al. 2017; Lee et al. 2014; Saintenac et al. 2018; Zhong et al. 2017). However, the vast majority of genes and encoded proteins remain uncharacterized in the laboratory (Talbot 2015).

Recently, there has been a community-wide effort to develop numerous tools, techniques, and resources for $Z$. tritici. This research toolkit includes mutants in the nonhomologous end joining pathway for highly efficient gene targeting (Sidhu et al. 2015a), optimization of conditional expression systems (Marchegiani et al. 2015), a range of fluorescent translational gene fusion for subcellular localization studies (Kilaru et al. 2017, 2015), optimized virulence assays (Fones et al. 2015), and a suite of Gateway destination vectors suitable for Agrobacterium tumefaciens-mediated transformation (Idnurm et al. 2017; Mehrabi et al. 2015; Sidhu et al. 2015b). These Gateway destination vectors have been validated using a pilot Gateway entry library to generate 32 overexpression mutants, which were phenotypically screened to demonstrate a role of the putative fungal-specific transcription factor-encoding gene almA for in vitro hyphal growth (Cairns et al. 2015).

Vol. 32, No. 12, 2019 / 1565 
In this study, we report the generation of an improved functional genomics community resource to supplement these tools, by generating a Gateway-compatible $Z$. triticiORFeome, which, to our knowledge, is the first such library for a plant-infecting fungus. This library is compatible with numerous Gateway destination vectors that have multiple functionality in Z. tritici, including numerous selection markers, epitope tags, and promoters (Alberti et al. 2007; Mehrabi et al. 2015). For ORFeome construction, we first screened the IP0323 reference genome for high-confidence gene models, yielding 4,075 candidate ORFs from a possible 10,933 predicted genes. These were PCR-amplified from genomic DNA and were cloned into the Gateway entry vector pDONR207. Quality of ORF sequences was verified by a combination of Sanger and Illumina sequencing, yielding 3,022 plasmids that passed quality control checks with $100 \%$ sequence verification.

The Z. tritici ORFeome described in this study is available to the research community. This resource can be rapidly utilized to interrogate the broadest aspects of $Z$. tritici biology, including identification of novel drug targets, mechanisms of drug detoxification and resistance, and pathogen virulence factors, which may ultimately enable development of new disease control strategies.

For ORFeome construction, E. coli One Shot $c c d B$ Survival 2 T1R were used for propagation of pDONR207 (Invitrogen) and destination vectors. All Gateway entry and expression vectors were propagated in $E$. coli $\mathrm{DH} 5 \alpha$ (Invitrogen).

For generation of Gateway entry vectors, this study utilized the Gateway donor vector pDONR207 (Invitrogen), which contains a gentamicin resistance gene, for selection in $E$. coli. This plasmid also contains a $c c d B$ gene flanked by attP sequences for Gateway-mediated recombination using the BP reaction.

Generation of Gateway entry vectors was conducted as described previously (Cairns et al. 2015). For PCR amplification of each gene of interest, forward primers were designed to include the attB1 site (ggggacaagtttgtacaaaaaagcaggcttg) and the first $20 \mathrm{bp}$ of the gene and reverse primers to include the attB2 site (ggggaccacttgtacaagaaagctgggtc) and the last $20 \mathrm{bp}$ of the gene. The stop codon was excluded to enable c-terminal epitope tagging by the end user. Primers were synthesized by Sigma-Aldrich UK and are listed in Supplementary File S1. PCRs were conducted using Phusion high-fidelity DNA polymerase (NEB) with a $65^{\circ} \mathrm{C}$ primer annealing temperature, an extension of $30 \mathrm{~s} / \mathrm{kb}$, using Z. tritici IP0323 genomic DNA as template. PCR amplicons of predicted sizes were confirmed by gel electrophoresis, were polyethylene glycol- purified, and were suspended in $10 \mu \mathrm{l}$ Tris-EDTA (TE) buffer (40 mM TRIS base, $20 \mathrm{mM}$ glacial acetic acid, $0.1 \mathrm{mM}$ EDTA, pH 8). For construction of Gateway entry vectors, $150 \mathrm{ng}$ of pDONR207 was mixed with $2.5 \mu \mathrm{l}$ of purified PCR product, $0.5 \mu \mathrm{l}$ of Gateway BP Clonase with TE buffer added to a total volume of $10 \mu \mathrm{l}$. Reactions were incubated at $25^{\circ} \mathrm{C}$ for 12 to $24 \mathrm{~h}$ and were then treated with Proteinase $\mathrm{K}$ (Invitrogen), following the manufacturer instructions. E. coli $\mathrm{DH} 5 \alpha$ was transformed with $5 \mu$ l of each reaction mixture. Luria Bertani (LB) supplemented with gentamicin $(50 \mu \mathrm{g} / \mathrm{ml})$ was subsequently used to select transformants, which were grown overnight in LB medium with selection, and plasmids were extracted using Plasmid mini kit (Qiagen). Plasmids were indexed and stored in 96 -well plates and at $-20^{\circ} \mathrm{C}$.

In order to confirm replacement of the $c c d B$ gene with the ORF encoding sequence and to confirm high fidelity PCR amplification, a total of 688 Gateway entry vectors were randomly selected and Sanger-sequenced (Eurofins) using primer GOXF (tcgcgttaacgctagcatgga). Quality control reactions are summarized in Supplementary File S2, which also gives plate co-ordinates for plasmid requests. A second quality-control experiment was conducted using two rounds of Illumina HiSeq 2500 sequencing of 3,396 pooled Gateway entry vectors. Raw sequencing data are available at the Sequencing Read Archive (Leinonen et al. 2011) (accession SRX1267196 and SRX1265386).

Evaluation of the 10,933 predicted genes in the $Z$. tritici IP0323 reference genome (Goodwin et al. 2011) returned 4,075 high-confidence gene models that had unambiguous start and stop codons (data not shown). This analysis was conducted prior to RNA-seq analysis and comparative genomic analyses (Grandaubert et al. 2015), which have since improved $Z$. tritici gene models. High-confidence gene models were complemented with a total of 1,345 priority ORFs that had been requested during consultation with members of the $Z$. tritici research community. These latter ORFs were included in the ORFeome construction project even if they failed our gene model quality control. An overview of the ORFeome construction project is shown in Supplementary Figure S1. PCR amplification utilized

1566 / Molecular Plant-Microbe Interactions 
library are putatively involved in a diverse range of processes, including secreted proteins and putative effectors, biosynthesis of secondary metabolite toxins, drug detoxification, signal sensing and transduction, and regulation of gene expression, among many others (Table 1), and will therefore facilitate functional genomic experiments for diverse aspects of $Z$. tritici biology.

Our strategy prioritized high-confidence gene models for ORFeome construction over a genome-wide cloning approach. While this has resulted in a partial ORFeome for $Z$. tritici IP0323, we believe that a focus on accurate gene models will avoid large-scale future updates of this resource. For example, the first $C$. elegans ORFeome (Reboul et al. 2003) underwent various revisions and additions due to improved gene model predictions (Lamesch et al. 2004). More importantly, high-confidence gene models will likely limit expression of incorrect ORFs during cost and labor-intensive experiments by end users.

ORFeomes for several model organisms are amplified intron-free sequences from cDNA libraries (Lamesch et al. 2004; Wiemann et al. 2016). In contrast, we amplified ORF sequences from genomic DNA in order to maintain the opportunity to generate alternative splice variants (e.g., due to intron skipping) in subsequent $Z$. tritici overexpression or localization experiments. While the extent of alternative splicing in fungi is not comprehensively determined, an estimated $6.1 \%$ of $Z$. tritici genes have splice variants (Grützmann et al. 2014). Alternative splicing is thought to predominantly occur for genes required for virulence, multicellularity, and dimorphic switching (Grützmann et al. 2014). Our ORFeome will therefore facilitate the study of splice variants that may have critical impacts on infection, or, alternatively, encode promising drug targets in this pathogen.

It should be noted that the ORFeome was constructed using isolate IP0323 (Goodwin et al. 2011). While this strain is commonly used by the research community, IP0323 was isolated in 1984 and is sensitive to crop protection chemistries to which current field isolates have evolved resistance. Thus, the resource may be limited for understanding resistance to such antifungals.

We have previously demonstrated that the application of a pilot $(n=32)$ collection of putative DNA-binding protein-encoding genes in entry vectors can enable medium-throughput gene functional analyses in Z. tritici (Cairns et al. 2015). The ORFeome generated in this study will drastically increase the throughput of these capabilities for the research community. We predict that functional genomics in $Z$. tritici will enable systems-level understanding of a diverse range of processes, including but not limited to growth and development, sensing and signal transduction, virulence, host-pathogen interactions, toxin biosynthesis, drug resistance, and chemical-genetic interactions. Such advances may ultimately lead to novel fungicide development and development of novel resistant wheat cultivars.

\section{Literature Cited}

Aken, B. L., Ayling, S., Barrell, D., Clarke, L., Curwen, V., Fairley, S., Fernandez Banet, J., Billis, K., García Girón, C., Hourlier, T., Howe, K., Kähäri, A., Kokocinski, F., Martin, F. J., Murphy, D. N., Nag, R., Ruffier, M., Schuster, M., Tang, Y. A., Vogel, J.-H., White, S., Zadissa, A., Flicek, P., and Searle, S. M. J. 2016. The Ensembl gene annotation system. Database (Oxford) 2016: baw093.

Alberti, S., Gitler, A. D., and Lindquist, S. 2007. A suite of Gateway ${ }^{\circledR}$ cloning vectors for high-throughput genetic analysis in Saccharomyces cerevisiae. Yeast 24: 913-919.

Cairns, T., and Meyer, V. 2017. In silico prediction and characterization of secondary metabolite biosynthetic gene clusters in the wheat pathogen Zymoseptoria tritici. BMC Genomics 18:631.

Cairns, T. C., Sidhu, Y. S., Chaudhari, Y. K., Talbot, N. J., Studholme, D. J., and Haynes, K. 2015. Construction and high-throughput phenotypic screening of Zymoseptoria tritici over-expression strains. Fungal Genet. Biol. 79:110-117.

Cairns, T. C., Studholme, D. J., Talbot, N. J., and Haynes, K. 2016. New and improved techniques for the study of pathogenic fungi. Trends Microbiol. 24:35-50.

Chauvel, M., Nesseir, A., Cabral, V., Znaidi, S., Goyard, S., Bachellier-Bassi, S., Firon, A., Legrand, M., Diogo, D., Naulleau, C., Rossignol, T., and d'Enfert, C. 2012. A versatile overexpression strategy in the pathogenic yeast Candida albicans: Identification of regulators of morphogenesis and fitness. PLoS One 7:e45912.
Chowdhary, A., Kathuria, S., Xu, J., and Meis, J. F. 2013. Emergence of azoleresistant Aspergillus fumigatus strains due to agricultural azole use creates an increasing threat to human health. PLOS Pathog. 9:e1003633.

Denning, D. W., and Bromley, M. J. 2015. How to bolster the antifungal pipeline. Science 347:1414-1416.

Dunlap, J. C., Borkovich, K. A., Henn, M. R., Turner, G. E., Sachs, M. S., Glass, N. L., McCluskey, K., Plamann, M., Galagan, J. E., Birren, B. W., Weiss, R. L., Townsend, J. P., Loros, J. J., Nelson, M. A., Lambreghts, R., Colot, H. V., Park, G., Collopy, P., Ringelberg, C., Crew, C., Litvinkova, L., DeCaprio, D., Hood, H. M., Curilla, S., Shi, M., Crawford, M., Koerhsen, M., Montgomery, P., Larson, L., Pearson, M., Kasuga, T., Tian, C., Baştürkmen, M., Altamirano, L., and Xu, J. 2007. Enabling a community to dissect an organism: Overview of the Neurospora functional genomics project. Adv. Genet. 57: 49-96.

Fisher, M. C., Henk, D. A., Briggs, C. J., Brownstein, J. S., Madoff, L. C., McCraw, S. L., and Gurr, S. J. 2012. Emerging fungal threats to animal, plant and ecosystem health. Nature 484:186-194.

Fones, H., and Gurr, S. 2015. The impact of Septoria tritici blotch disease on wheat: An EU perspective. Fungal Genet. Biol. 79:3-7.

Fones, H. N., Steinberg, G., and Gurr, S. J. 2015. Measurement of virulence in Zymoseptoria triticithrough low inoculum-density assays. Fungal Genet. Biol. 79: 89-93. 
Gelperin, D. M., White, M. A., Wilkinson, M. L., Kon, Y., Kung, L. A., Wise, K. J., LopezHoyo, N., Jiang, L., Piccirillo, S., Yu, H., Gerstein, M., Dumont, M. E., Phizicky, E. M., Snyder, M., and Grayhack, E. J. 2005. Biochemical and genetic analysis of the yeast proteome with a movable ORF collection. Genes Dev. 19:2816-2826.

Giaever, G., Chu, A. M., Ni, L., Connelly, C., Riles, L., Véronneau, S., Dow, S., LucauDanila, A., Anderson, K., André, B., Arkin, A. P., Astromoff, A., El-Bakkoury, M., Bangham, R., Benito, R., Brachat, S., Campanaro, S., Curtiss, M., Davis, K., Deutschbauer, A., Entian, K. D., Flaherty, P., Foury, F., Garfinkel, D. J., Gerstein, M., Gotte, D., Güldener, U., Hegemann, J. H., Hempel, S., Herman, Z., Jaramillo, D. F., Kelly, D. E., Kelly, S. L., Kötter, P., LaBonte, D., Lamb, D. C., Lan, N., Liang, H., Liao, H., Liu, L., Luo, C., Lussier, M., Mao, R., Menard, P., Ooi, S. L., Revuelta, J. L., Roberts, C. J., Rose, M., Ross-Macdonald, P., Scherens, B., Schimmack, G., Shafer, B., Shoemaker, D. D., Sookhai-Mahadeo, S., Storms, R. K., Strathern, J. N., Valle, G., Voet, M., Volckaert, G., Wang, C. Y., Ward, T. R., Wilhelmy, J., Winzeler, E. A., Yang, Y., Yen, G., Youngman, E., Yu, K., Bussey, H., Boeke, J. D., Snyder, M., Philippsen, P., Davis, R. W., and Johnston, M. 2002. Functional profiling of the Saccharomyces cerevisiae genome. Nature 418: 387-391.

Giaever, G., and Nislow, C. 2014. The yeast deletion collection: A decade of functional genomics. Genetics 197:451-465.

Gong, W., Shen, Y.-P., Ma, L.-G., Pan, Y., Du, Y.-L., Wang, D.-H., Yang, J.-Y., Hu, L.-D., Liu, X.-F., Dong, C.-X., Ma, L., Chen, Y.-H., Yang, X.-Y., Gao, Y., Zhu, D., Tan, X., Mu, J.-Y., Zhang, D.-B., Liu, Y.-L., Dinesh-Kumar, S. P., Li, Y., Wang, X.-P., Gu, H.-Y., Qu, L.-J., Bai, S.-N., Lu, Y.-T., Li, J.-Y., Zhao, J.-D., Zuo, J., Huang, H., Deng, X.-W., and Zhu, Y.-X. 2004. Genome-wide ORFeome cloning and analysis of Arabidopsis transcription factor genes. Plant Physiol. 135:773-782.

Goodwin, S. B., M'barek, S. B., Dhillon, B., Wittenberg, A. H., Crane, C. F., Hane, J. K., Foster, A. J., Van der Lee, T. A., Grimwood, J., Aerts, A., Antoniw, J., Bailey, A., Bluhm, B., Bowler, J., Bristow, J., van der Burgt, A., Canto-Canché, B., Churchill, A. C., Conde-Ferràez, L., Cools, H. J., Coutinho, P. M., Csukai, M., Dehal, P., De Wit, P., Donzelli, B., van de Geest, H. C., van Ham, R. C., Hammond-Kosack, K. E., Henrissat, B., Kilian, A., Kobayashi, A. K., Koopmann, E., Kourmpetis, Y., Kuzniar, A., Lindquist, E., Lombard, V., Maliepaard, C., Martins, N., Mehrabi, R., Nap, J. P., Ponomarenko, A., Rudd, J. J., Salamov, A., Schmutz, J., Schouten, H. J., Shapiro, H., Stergiopoulos, I., Torriani, S. F., Tu, H., de Vries, R. P., Waalwijk, C., Ware, S. B., Wiebenga, A., Zwiers, L. H., Oliver, R. P., Grigoriev, I. V., and Kema, G. H. 2011. Finished genome of the fungal wheat pathogen Mycosphaerella graminicola reveals dispensome structure, chromosome plasticity, and stealth pathogenesis. PLoS Genet. 7:e1002070.

Grandaubert, J., Bhattacharyya, A., and Stukenbrock, E. H. 2015. RNA-seq-based gene annotation and comparative genomics of four fungal grass pathogens in the genus Zymoseptoria identify novel orphan genes and species-specific invasions of transposable elements. G3-Genes Genom. Genet. 5:1323-1333.

Grützmann, K., Szafranski, K., Pohl, M., Voigt, K., Petzold, A., and Schuster, S. 2014. Fungal alternative splicing is associated with multicellular complexity and virulence: A genome-wide multi-species study. DNA Res. 21:27-39.

Habig, M., Quade, J., and Stukenbrock, E. H. 2017. Forward genetics approach reveals host genotype-dependent importance of accessory chromosomes in the fungal wheat pathogen Zymoseptoria tritici. MBio 8:e01919-17.

Homann, O. R., Dea, J., Noble, S. M., and Johnson, A. D. 2009. A phenotypic profile of the Candida albicans regulatory network. PLoS Genet. 5:e1000783.

Idnurm, A., Bailey, A. M., Cairns, T. C., Elliott, C. E., Foster, G. D., laniri, G., and Jeon, J. 2017. A silver bullet in a golden age of functional genomics: The impact of Agrobacterium-mediated transformation of fungi. Fungal Biol. Biotechnol. 4:6.

Jeon, J., Park, S.-Y., Chi, M.-H., Choi, J., Park, J., Rho, H.-S., Kim, S., Goh, J., Yoo, S., Choi, J., Park, J.-Y., Yi, M., Yang, S., Kwon, M.-J., Han, S.-S., Kim, B. R., Khang, C. H., Park, B., Lim, S.-E., Jung, K., Kong, S., Karunakaran, M., Oh, H.-S., Kim, H., Kim, S., Park, J., Kang, S., Choi, W.-B., Kang, S., and Lee, Y.-H. 2007. Genome-wide functional analysis of pathogenicity genes in the rice blast fungus. Nat. Genet. 39:561-565.

Kettles, G. J., Bayon, C., Canning, G., Rudd, J. J., and Kanyuka, K. 2017. Apoplastic recognition of multiple candidate effectors from the wheat pathogen Zymoseptoria tritici in the nonhost plant Nicotiana benthamiana. New Phytol. 213: 338-350.

Kilaru, S., Schuster, M., Ma, W., and Steinberg, G. 2017. Fluorescent markers of various organelles in the wheat pathogen Zymoseptoria tritici. Fungal Genet. Biol. 105:16-27.

Kilaru, S., Schuster, M., Studholme, D., Soanes, D., Lin, C., Talbot, N. J., and Steinberg, G. 2015. A codon-optimized green fluorescent protein for live cell imaging in Zymoseptoria tritici. Fungal Genet. Biol. 79:125-131.
King, R., Urban, M., Lauder, R. P., Hawkins, N., Evans, M., Plummer, A., Halsey, K., Lovegrove, A., Hammond-Kosack, K., and Rudd, J. J. 2017. A conserved fungal glycosyltransferase facilitates pathogenesis of plants by enabling hyphal growth on solid surfaces. PLoS Pathog. 13:e1006672.

Lamesch, P., Milstein, S., Hao, T., Rosenberg, J., Li, N., Sequerra, R., Bosak, S., Doucette-Stamm, L., Vandenhaute, J., Hill, D. E., and Vidal, M. 2004. C. elegans ORFeome version 3.1: Increasing the coverage of ORFeome resources with improved gene predictions. Genome Res. 14:2064-2069.

Lee, W. S., Rudd, J. J., Hammond-Kosack, K. E., and Kanyuka, K. 2014. Mycosphaerella graminicola LysM effector-mediated stealth pathogenesis subverts recognition through both CERK1 and CEBiP homologues in wheat. Mol. Plant-Microbe Interact. 27:236-243.

Legrand, M., Bachellier-Bassi, S., Lee, K. K., Chaudhari, Y., Tournu, H., Arbogast, L., Boyer, H., Chauvel, M., Cabral, V., Maufrais, C., Nesseir, A., Maslanka, I. Permal, E., Rossignol, T., Walker, L. A., Zeidler, U., Znaidi, S., Schoeters, F., Majgier, C., Julien, R. A., Ma, L., Tichit, M., Bouchier, C., Van Dijck, P., Munro, C. A., and d'Enfert, C. 2018. Generating genomic platforms to study Candida albicans pathogenesis. Nucleic Acids Res. 46:6935-6949.

Leinonen, R., Sugawara, H., and Shumway, M.; International Nucleotide Sequence Database Collaboration. 2011. The sequence read archive. Nucleic Acids Res. 39:D19-D21.

Li, Q. R., Carvunis, A. R., Yu, H., Han, J. D. J., Zhong, Q., Simonis, N., Tam, S., Hao, T., Klitgord, N. J., Dupuy, D., Mou, D., Wapinski, I., Regev, A., Hill, D. E., Cusick, M. E., and Vidal, M. 2008. Revisiting the Saccharomyces cerevisiae predicted ORFeome. Genome Res. 18:1294-1303.

Liu, O. W., Chun, C. D., Chow, E. D., Chen, C., Madhani, H. D., and Noble, S. M. 2008. Systematic genetic analysis of virulence in the human fungal pathogen Cryptococcus neoformans. Cell 135:174-188.

Marchegiani, E., Sidhu, Y., Haynes, K., and Lebrun, M. H. 2015. Conditional gene expression and promoter replacement in Zymoseptoria tritici using fungal nitrate reductase promoters. Fungal Genet. Biol. 79:174-179.

Matsuyama, A., Arai, R., Yashiroda, Y., Shirai, A., Kamata, A., Sekido, S., Kobayashi, Y., Hashimoto, A., Hamamoto, M., Hiraoka, Y., Horinouchi, S., and Yoshida, M. 2006. ORFeome cloning and global analysis of protein localization in the fission yeast Schizosaccharomyces pombe. Nat. Biotechnol. 24:841-847.

Mehrabi, R., Mirzadi Gohari, A., da Silva, G. F., Steinberg, G., Kema, G. H. J., and de Wit, P. J. G. M. 2015. Flexible gateway constructs for functional analyses of genes in plant pathogenic fungi. Fungal Genet. Biol. 79:186-192.

Meyer, V., Andersen, M. R., Brakhage, A. A., Braus, G. H., Caddick, M. X., Cairns, T. C., de Vries, R. P., Haarmann, T., Hansen, K., Hertz-Fowler, C., Krappmann, S., Mortensen, U. H., Peñalva, M. A., Ram, A. F. J., and Head, R. M. 2016. Current challenges of research on filamentous fungi in relation to human welfare and a sustainable bio-economy: A white paper. Fungal Biol. Biotechnol. 3:6.

Möller, M., Habig, M., Freitag, M., and Stukenbrock, E. H. 2018. Extraordinary genome instability and widespread chromosome rearrangements during vegetative growth. Genetics 210:517-529.

Noble, S. M., French, S., Kohn, L. A., Chen, V., and Johnson, A. D. 2010. Systematic screens of a Candida albicans homozygous deletion library decouple morphogenetic switching and pathogenicity. Nat. Genet. 42:590-598.

Plissonneau, C., Hartmann, F. E., and Croll, D. 2018. Pangenome analyses of the wheat pathogen Zymoseptoria tritici reveal the structural basis of a highly plastic eukaryotic genome. BMC Biol. 16:5.

Rajagopala, S. V., Yamamoto, N., Zweifel, A. E., Nakamichi, T., Huang, H. K., Mendez-Rios, J. D., Franca-Koh, J., Boorgula, M. P., Fujita, K., Suzuki, K., Hu, J. C., Wanner, B. L., Mori, H., and Uetz, P. 2010. The Escherichia coli K-12 ORFeome: A resource for comparative molecular microbiology. BMC Genomics 11:470.

Reboul, J., Vaglio, P., Rual, J. F., Lamesch, P., Martinez, M., Armstrong, C. M., Li, S., Jacotot, L., Bertin, N., Janky, R., Moore, T., Hudson, J. R., Jr., Hartley, J. L., Brasch, M. A., Vandenhaute, J., Boulton, S., Endress, G. A., Jenna, S., Chevet, E., Papasotiropoulos, V., Tolias, P. P., Ptacek, J., Snyder, M., Huang, R., Chance, M. R., Lee, H., Doucette-Stamm, L., Hill, D. E., and Vidal, M. 2003. C. elegans ORFeome version 1.1: Experimental verification of the genome annotation and resource for proteome-scale protein expression. Nat. Genet. 34:35-41.

Roemer, T., Jiang, B., Davison, J., Ketela, T., Veillette, K., Breton, A., Tandia, F., Linteau, A., Sillaots, S., Marta, C., Martel, N., Veronneau, S., Lemieux, S., Kauffman, S., Becker, J., Storms, R., Boone, C., and Bussey, H. 2003. Largescale essential gene identification in Candida albicans and applications to antifungal drug discovery. Mol. Microbiol. 50:167-181. 
Rudd, J. J., Kanyuka, K., Hassani-Pak, K., Derbyshire, M., Andongabo, A., Devonshire, J., Lysenko, A., Saqi, M., Desai, N. M., Powers, S. J., Hooper, J., Ambroso, L., Bharti, A., Farmer, A., Hammond-Kosack, K. E., Dietrich, R. A., and Courbot, M. 2015. Transcriptome and metabolite profiling of the infection cycle of Zymoseptoria tritici on wheat reveals a biphasic interaction with plant immunity involving differential pathogen chromosomal contributions and a variation on the hemibiotrophic lifestyle definition. Plant Physiol. 167:1158-1185.

Saintenac, C., Lee, W.-S., Cambon, F., Rudd, J. J., King, R. C., Marande, W., Powers, S. J., Bergès, H., Phillips, A. L., Uauy, C., Hammond-Kosack, K. E., Langin, T., and Kanyuka, K. 2018. Wheat receptor-kinase-like protein Stb6 controls gene-for-gene resistance to fungal pathogen Zymoseptoria tritici. Nat. Genet. 50:368-374.

Schwarzmüller, T., Ma, B., Hiller, E., Istel, F., Tscherner, M., Brunke, S., Ames, L., Firon, A., Green, B., Cabral, V., Marcet-Houben, M., Jacobsen, I. D., Quintin, J., Seider, K., Frohner, I., Glaser, W., Jungwirth, H., Bachellier-Bassi, S., Chauvel, M., Zeidler, U., Ferrandon, D., Gabaldón, T., Hube, B., d'Enfert, C., Rupp, S., Cormack, B., Haynes, K., and Kuchler, K. 2014. Systematic phenotyping of a large-scale Candida glabrata deletion collection reveals novel antifungal tolerance genes. PLoS Pathog. 10:e1004211.

Sidhu, Y. S., Cairns, T. C., Chaudhari, Y. K., Usher, J., Talbot, N. J., Studholme, D. J., Csukai, M., and Haynes, K. 2015a. Exploitation of sulfonylurea resistance marker and non-homologous end joining mutants for functional analysis in Zymoseptoria tritici. Fungal Genet. Biol. 79:102-109.

Sidhu, Y. S., Chaudhari, Y. K., Usher, J., Cairns, T. C., Csukai, M., and Haynes, K. 2015b. A suite of Gateway ${ }^{\circledR}$ compatible ternary expression vectors for functional analysis in Zymoseptoria tritici. Fungal Genet. Biol. 79:180-185.

Son, H., Seo, Y. S., Min, K., Park, A. R., Lee, J., Jin, J. M., Lin, Y., Cao, P., Hong, S. Y., Kim, E. K., Lee, S. H., Cho, A., Lee, S., Kim, M. G., Kim, Y., Kim, J. E., Kim, J. C., Choi, G. J., Yun, S. H., Lim, J. Y., Kim, M., Lee, Y. H., Choi, Y. D., and Lee, Y. W. 2011. A phenome-based functional analysis of transcription factors in the cereal head blight fungus, Fusarium graminearum. PLoS Pathog. 7:e1002310.

Sperschneider, J., Dodds, P. N., Gardiner, D. M., Singh, K. B., and Taylor, J. M. 2018. Improved prediction of fungal effector proteins from secretomes with EffectorP 2.0. Mol. Plant Pathol. 19:2094-2110.

Steinberg, G. 2015. Cell biology of Zymoseptoria tritici: Pathogen cell organization and wheat infection. Fungal Genet. Biol. 79:17-23.
Talbot, N. J. 2015. Taming a wild beast: Developing molecular tools and new methods to understand the biology of Zymoseptoria tritici. Fungal Genet. Biol. 79:193-195.

Walhout, A. J., Temple, G. F., Brasch, M. A., Hartley, J. L., Lorson, M. A., van den Heuvel, S., and Vidal, M. 2000. GATEWAY recombinational cloning: Application to the cloning of large numbers of open reading frames or ORFeomes. Methods Enzymol. 328:575-592.

Wiemann, S., Pennacchio, C., Hu, Y., Hunter, P., Harbers, M., Amiet, A., Bethel, G., Busse, M., Carninci, P., Diekhans, M., Dunham, I., Hao, T., Harper, J. W. Hayashizaki, Y., Heil, O., Hennig, S., Hotz-Wagenblatt, A., Jang, W., Jöcker, A., Kawai, J., Koenig, C., Korn, B., Lambert, C., LeBeau, A., Lu, S., Maurer, J., Moore, T., Ohara, O., Park, J., Rolfs, A., Salehi-Ashtiani, K., Seiler, C., Simmons, B., Van Brabant Smith, A., Steel, J., Wagner, L., Weaver, T., Wellenreuther, R., Yang, S., Vidal, M., and Gerhard, S.; ORFeome Collaboration. 2016. The ORFeome Collaboration: A genome-scale human ORF-clone resource. Nat. Methods 13: 191-192.

Winzeler, E. A., Shoemaker, D. D., Astromoff, A., Liang, H., Anderson, K., Andre, B., Bangham, R., Benito, R., Boeke, J. D., Bussey, H., Chu, A. M., Connelly, C., Davis, K., Dietrich, F., Dow, S. W., El Bakkoury, M., Foury, F., Friend, S. H., Gentalen, E., Giaever, G., Hegemann, J. H., Jones, T., Laub, M., Liao, H., Liebundguth, N., Lockhart, D. J., Lucau-Danila, A., Lussier, M., M'Rabet, N., Menard, P., Mittmann, M., Pai, C., Rebischung, C., Revuelta, J. L., Riles, L., Roberts, C. J., Ross-MacDonald, P., Scherens, B., Snyder, M., SookhaiMahadeo, S., Storms, R. K., Véronneau, S., Voet, M., Volckaert, G., Ward, T. R., Wysocki, R., Yen, G. S., Yu, K., Zimmermann, K., Philippsen, P., Johnston, M., and Davis, R. W. 1999. Functional characterization of the S. cerevisiae genome by gene deletion and parallel analysis. Science 285:901-906.

Zhan, J., Pettway, R. E., and McDonald, B. A. 2003. The global genetic structure of the wheat pathogen Mycosphaerella graminicola is characterized by high nuclear diversity, low mitochondrial diversity, regular recombination, and gene flow. Fungal Genet. Biol. 38:286-297.

Zhong, Z., Marcel, T. C., Hartmann, F. E., Ma, X., Plissonneau, C., Zala, M., Ducasse, A., Confais, J., Compain, J., Lapalu, N., Amselem, J., McDonald, B. A., Croll, D., and Palma-Guerrero, J. 2017. A small secreted protein in Zymoseptoria tritici is responsible for avirulence on wheat cultivars carrying the Stb6 resistance gene. New Phytol. 214:619-631. 